\title{
Faktor- Faktor yang Mempengaruhi Proses Alih Fungsi Lahan Padi Sawah di Kelurahan Kersanegara, Kecamatan Cibeureum, Kota Tasikmalaya, Provinsi Jawa Barat
}

\author{
Prilly Martunisa dan Trisna Insan Noor \\ Program Studi Agribisnis, Departemen Sosial Ekonomi, Fakultas Pertanian, Universitas \\ Padjadjaran, Sumedang, Indonesia \\ Email: prillymartunisa_06@yahoo.com,trisna.insan.noor@unpad.ac.id
}

\begin{abstract}
ABSTRAK
Pertanian selama ini hanya dihargai karena kemampuannya menghasilkan bahan pangan, sandang dan papan. Selain itu, pertanian juga memberikan berbagai jasalfungsi positif di bidang sosial budaya, ekonomi dan lingkungan yang dikenal dengan multifungsi pertanian dan belum banyak diketahui masyarakat. Seiring dengan pertumbuhan penduduk dan perekonomian banyak terjadi alih fungsi lahan terutama lahan padi sawah untuk berbagai kepentingan. Penelitian ini bertujuan untuk mengetahui faktor-faktor dan faktor dominan yang mempengaruhi terjadinya alih fungsi lahan padi sawah. Penelitian ini dilakukan di Kelurahan Kersanagara, Kecamatan Cibeureum, Kota Tasikmalaya, Jawa Barat. Teknik pengambilan data dilakukan adalah wawancara kepada 45 orang petani yang pernah melakukan alih fungsi lahan padi sawah. Desain penelitian ini adalah kuantitatif deskriptif. Analisis data menggunakan regresi linier berganda dengan alat bantu SPSS version 24. Hasil penelitian menunjukkan bahwa umur petani, pendapatan petani, luas kepemilikkan lahan, sistem waris, pengaruh tetangga yang mengalihfungsikan lahannya, pengaruh pengusaha/investor, keadaan lingkungan, kebijakan pemerintah dan pendidikan petani secara keseluruhan memberikan pengaruh nyata terhadap alih fungsi lahan padi sawah. Variabel umur petani dan luas kepemilikkan lahan menjadi faktor yang dominan terhadap terjadinya alih fungsi lahan padi sawah.
\end{abstract}

Kata kunci: faktor-faktor, alih fungsi, lahan padi sawah

\begin{abstract}
Agriculture has been only valued for its ability to produce primary needs of human being. In addition, agriculture also provides a range of positive services / functions at socio-cultural, economic and environmental fields known as multifunctional agriculture and have not been known to the public yet. Along with the raising population and the growth of economic, there has been occured many land conversion, particularly for paddy fields as it for several needs. This land conversion is caused by several factors. The purpose of this research is to identify the factors as well as to find the dominant among them that affect the land conversion of paddy fields. This research was conducted in Kelurahan Kersanagara, Kecamatan Cibeureum, Kota Tasikmalaya, Jawa Barat. In this research, the data was collected by interviewing 45 farmers who ever did changes to the utility of paddy land. The design of this study is quantitative descriptive. Data analysis using multiple linear regression with SPSS version tool 24. This research shows the results that the age of farmers, farmers income, land ownership, inheritance systems, the influance of neighbors that also converted land, influence of investors, environmental conditions, government policies and farmer education generally gives a real effect on the conversion of paddy land. After all, the age of farmers and the land ownership become the dominant factor toward the land conversion that occured.
\end{abstract}

Keywords: factors, land conversion, paddy field 


\section{PENDAHULUAN}

Sebagai penyokong utama kehidupan, pertanian perlu dilihat dalam dimensi yang lebih luas, yaitu tidak hanya semata-mata sebagai penghasil produk pertanian yang tampak nyata dan dapat dipasarkan (tangible dan marketable), tetapi juga sebagai penghasil jasa yang tidak tampak nyata (intangible). Jasa tersebut tidak/belum diperhitungkan di dalam sistem pasar (non-marketable). Berbagai jasa atau fungsi positif yang dapat disumbangkan oleh pertanian dikenal dengan multifungsi pertanian [1]. Multifungsi pertanian mencakup fungsi lingkungan yaitu pencegah banjir, pengendali erosi tanah, konservasi air tanah, penambat karbon atau gas rumah kaca, penyegar udara, pendaur ulang sampah organik, dan pemelihara keanekaragaman hayati [1].

Dengan adanya konsep multifungsi pertanian ini diharapkan dapat mendudukkan pertanian pada kedudukan yang semestinya. Namun pengetahuan masyarakat akan multifungsi pertanian masih rendah, sehingga menyebabkan sektor pertanian mudah dikalahkan oleh sektor lain, seperti sektor perdagangan, jasa dan industri. Menurut Adimihardja [2] dengan rendahnya pengetahuan masyarakat terhadap multifungsi pertanian dapat berimplikasi pada rendahnya penghargaan terhadap pertanian. Sejalan dengan Nurmanaf [3] bahwa terjadinya proses alih fungsi lahan sawah ke penggunaan lain salah satunya disebabkan oleh kurangnya kepedulian banyak pihak atas fungsi - fungsi yang diembannya.

Selain itu terdapat faktor eksternal yang mendorong percepatan proses alih fungsi lahan tersebut yaitu gencarnya pembangunan sektor nonpertanian dalam memperoleh lahan yang siap pakai, terutama ditinjau dari karakteristik biofisik dan aksesibilitas [2]. Kebutuhan tersebut pada umumnya dapat terpenuhi oleh lahan pertanian beririgasi yang mana sebagian besar lahan sawah yang terkonversi itu pada mulanya beririgasi teknis dengan produktivitas yang tinggi [4]

Untuk menindaklajuti hal tersebut terdapat kebijakan mengenai perlindungan lahan pertanian. Kebijakan tersebut tercantum dalam Undang-Undang Republik Indonesia Nomor 41 Tahun 2009 Tentang Perlindungan Lahan Pertanian Pangan Berkelanjutan. Dalam undang-undang tersebut, lahan memiliki fungsi utama untuk mendukung kemandirian, ketahanan, dan kedaulatan pangan nasional.

Salah satu daerah di Indonesia yang telah menerapkan kebijakan mengenai perlindungan lahan pertanian adalah Kota Tasikmalaya Provinsi Jawa Barat. Kebijakan tersebut dimuat dalam Peraturan Daerah Kota Tasikmalaya Nomor 4 Tahun 2012 paragraf 7 Pasal 49 ayat 2, Tentang Rencana Tata Ruang Wilayah (RTRW) Kota Tasikmalaya Tahun 2011-2031. Dalam peraturan daerah tersebut dinyatakan bahwa jumlah lahan pertanian pangan ini seluas 492 hektar yang tersebar di empat wilayah kecamatan, yaitu Kecamatan Mangkubumi, Kawalu. Purbaratu dan Cibeureum.

Namun terjadi alih fungsi lahan padi sawah di beberapa kecamatan yang termasuk dalam LP2B yang tentunya menjadi salah satu ancaman terhadap ketahanan pangan Kota Tasikmalaya (Tabel 1). Tahun 2016 terjadi pengurangan jumlah luas lahan sebesar 5 ha di Kecamatan Cibeureum, padahal seluruh kelurahan di Kecamatan Cibeureum ini termasuk dalam lahan pertanian pangan berkelanjutan dan luas LP2B nya terbesar.

Pengurangan lahan pun terjadi di wilayah LP2B lainnya yakni di Kecamatan Purbaratu sebesar 5 ha terjadi pada tahun 2012 pada saat baru ditetapkan kebijakan LP2B, berbeda dengan Kecamatan Cibeureum yang alih fungsi lahannya terjadi dalam kurun waktu satu tahun yang lalu yakni setelah 5 tahun ditetapkan LP2B (Tabel 1). 
Faktor- Faktor yang Mempengaruhi Proses Alih Fungsi Lahan Padi Sawah di Kelurahan Kersanegara, Kecamatan Cibeureum, Kota Tasikmalaya, Provinsi Jawa Barat

Selanjutnya pengurangan lahan pun terjadi pada tahun 2016 di Kecamatan Mangkubumi sebesar 2 ha padahal kecamatan ini termasuk dalam LP2B. Jumlah pengurangan luas lahan di Kecamatan Mangkubumi lebih kecil jika dibandingkan dengan pengurangan luas lahan di Kecamatan Cibeureum. Selain di empat kecamatan diatas, pengurangan luas lahan sawah pun terjadi di Kecamatan Indihiang, Tawang, Cipedes, Tamansari dan Cihideung (Tabel 1), namun kecamatan - kecamatan tersebut diperuntukkan untuk pengembangan wilayah perkotaan, industri, perdagangan dan jasa.

Berdasarkan uraian tersebut, Kecamatan Cibeureum adalah kecamatan dengan jumlah luas lahan pertanian pangan berkelanjutan yang terbesar. Namun dengan jumlah alih fungsi lahan yang besar dan terjadi di akhir-akhir ini yakni pada tahun 2016. Hal ini diduga karena pesatnya pembangunan yang terjadi Kecamatan Cibeureum terutama untuk perumahan, pertokoan dan kawasan pendidikan. Dapat dilihat dari keadaan di sepanjang jalan nampak pembangunan - pembangunan perumahan yang berasal dari lahan sawah.

Selanjutnya Kelurahan Kersanagara adalah salah satu kelurahan di Kecamatan Cibeureum dengan jumlah luas lahan sawah terbesar yakni 145 ha tetapi dengan jumlah pembangunan dan alih fungsi lahan sawah paling tinggi di Kecamatan Cibeureum. Tingginya alih fungsi lahan pertanian di Kelurahan Kersanagara ini terkait dengan RTRW Kota Tasikmalaya yang akan menjadikan kawasan pendidikan berada di sekitar Kelurahan Kersanagara, sehingga mendorong tingginya pembangunan perumahan untuk memenuhi kebutuhan penduduk yang datang ke daerah ini. Tingginya pembangunan perumahan di Kelurahan Kersanagara karena adanya keinginan untuk investasi dalam bentuk rumah/perumahan. Kepemilikan rumah yang ada di salah satu perumahan yang sedang dibangun di Kelurahan Kersanagara ini banyak yang dimiliki oleh warga diluar Kota Tasikmalaya, seperti dari Kabupaten Tasikmalaya, Ciamis dan Banjar.

Berdasarkan hal tersebut, penelitian ini bertujuan untuk mengetahui faktor-faktor dan faktor dominan yang mempengaruhi terjadi alih fungsi lahan padi sawah di Kelurahan Kersanagara, Kecamatan Cibeureum, Kota Tasikmalaya, Provinsi Jawa Barat.

Tabel 1. Perkembangan Luas Baku Lahan Sawah Tahun 2012-2016

\begin{tabular}{llrrrrr}
\hline No. & Kecamatan & $\mathbf{2 0 1 2}(\mathbf{H a})$ & $\mathbf{2 0 1 3}(\mathbf{H a})$ & $\mathbf{2 0 1 4}(\mathbf{H a})$ & $\mathbf{2 0 1 5}(\mathbf{H a})$ & $\mathbf{2 0 1 6}(\mathbf{H a})$ \\
\hline 1 & Kawalu & 1.244 & 1.244 & 1.244 & 1.244 & 1.244 \\
\hline 2 & Tamansari & 802 & 802 & 802 & 802 & 798 \\
\hline 3 & Cibeureum & 763,5 & 763,5 & 763,5 & 763,5 & 758,5 \\
\hline 4 & Purbaratu & 504 & 499 & 499 & 499 & 499 \\
\hline 5 & Tawang & 91 & 89 & 87 & 87 & 87 \\
\hline 6 & Cihideung & 76 & 74 & 73 & 72 & 70 \\
\hline 7 & Mangkubumi & 1.134 & 1.134 & 1.134 & 1.134 & 1.132 \\
\hline 8 & Indihiang & 419 & 419 & 419 & 418 & 418 \\
\hline 9 & Bungursari & 693 & 693 & 693 & 693 & 693 \\
\hline 10 & Cipedes & 267 & 258 & 255 & 254 & 239 \\
\hline Jumlah & & $\mathbf{6 . 0 1 7}$ & $\mathbf{5 . 9 9 9}$ & $\mathbf{5 . 9 9 3}$ & $\mathbf{5 . 9 9 0}$ & $\mathbf{5 . 9 6 2}$ \\
\hline
\end{tabular}

Sumber: Dinas Pertanian Kota Tasikmalaya, 2017 


\section{METODE PENELITIAN}

Objek penelitian adalah faktor - faktor yang mempengaruhi terjadi alih fungsi lahan padi sawah sedangkan tempat penelitian dilaksanakan di Kelurahan Kersanagara, Kecamatan Cibeureum, Kota Tasikmalaya. pemilihan lokasi penelitian didasari karena Kelurahan Kersanagara ini merupakan kelurahan dengan luas lahan sawah yang terluas yakni sebesar 145 ha serta merupakan kelurahan dengan alih fungsi lahan yang tertinggi di Kecamatan Cibeureum.

Desain dari penelitian ini menggunakan desain penelitian kuantitatif deskriptif. Penelitian kuantitatif dilakukan untuk mengangkat variabel, fakta maupun fenomena-fenomena yang selanjutnya ditampilkan apa adanya sesuai pada waktu sekarang [5]. Metode deskriptif dimaksudkan untuk mengungkap atau menjelaskan data secara sistematis sesuai dengan keadaan lapangan yang sebenarnya. Penelitian ini menggunakan teknik penelitian suatu kasus dengan pengambilan data menggunakan metode survey. Metode survei digunakan agar mendapatkan data dari tempat tertentu yang alamiah dengan menggunakan kuesioner dan wawancara terstruktur [5].

\subsection{Analisis Deskriptif}

Data yang telah diperoleh dari lapangan akan di analisis secara deskriptif. Penelitian yang bersifat deskriptif adalah suatu penelitian yang berusaha untuk memberikan gambaran mengenai suatu fenomena, kondisi,keadaan yang seseungguhnya dari objek penelitian. Metode ini dilakukan dengan cara mengumpulkan, menyajikan, dan menganalisis data berdasarkan fakta yang ada. Kumpulan data mentah hasil dari lapangan akan disajikan dalam bentuk informasi yang ringkas seperti tabel, diagram dan grafik agar mudah dipahami.

\subsection{Analisis Regresi Linier Berganda}

Menurut Ghozali [6] analisis regresi mengestimasi hubungan antara variabel dependen dan variabel independen. Untuk melihat hubungan satu variabel dependen terhadap lebih dari satu variabel independen digunakan analisi regresi berganda (multiple regression analysis). Faktor-faktor yang mempengaruhi alih fungsi lahan diestimasi dengan memasukkan variabel-variabel bebas (independent) yang mempengaruhi alih fungsi lahan sebagai variabel terikat (dependent). Variabel bebas yang diduga berpengaruh terhadap alih fungsi lahan adalah umur petani, pendapatan petani, luas kepemilikkan lahan, sistem waris, tetangga yang mengalihfungsikan lahannya, pengusaha, kondisi lingkungan, kebijakan pemerintah dan pendidikan petani. Persamaan regresi yang digunakan adalah sebagai berikut:

$$
Y=a+\beta 1 X_{1}+\beta 2 X_{2}+\beta 3 X_{3}+\beta 4 X_{4}+\beta 5 X_{5}+\beta 6 X_{6}+\beta 7 X_{7}+\beta 8 X_{8}+\beta 9 X_{9}+e
$$

Keterangan :

$\mathrm{Y}=$ Alih Fungsi Lahan

$\mathrm{a}=$ Konstanta

$\beta 1=$ Koefisien regresi dari variabel $\mathrm{X}_{1}$ (Umur Petani)

$\mathrm{X}_{1}=$ Umur Petani

$\beta 2=$ Koefisien regresi dari variabel $X_{2}$ (Pendapatan Petani)

$\mathrm{X}_{2}=$ Pendapatan Petani

$\beta 3=$ Koefisien regresi dari variabel $X_{3}$ (Luas Kepemilikkan Lahan)

$\mathrm{X}_{3}=$ Luas Kepemilikkan Lahan

$\beta 4=$ Koefisien regresi dari variabel $\mathrm{X}_{4}$ (Sistem Waris)

$\mathrm{X}_{4}=$ Sistem Waris

$\beta 5=$ Koefisien regresi dari variabel $X_{5}$ (Tetangga yang Mengalihfungsikan lahannya

$\mathrm{X}_{5}=$ Tetangga yang Mengalihfungsikan Lahannya

$\beta 6=$ Koefisien regresi dari variabel $\mathrm{X}_{6}$ (Pengusaha)

$\mathrm{X}_{6}=$ Pengusaha

$\beta 7=$ Koefisien regresi dari variabel $X_{7}$ (Kondisi Lingkungan)

$\mathrm{X}_{7}=$ Kondisi Lingkungan

$\beta 8=$ Koefisien regresi dari variabel $\mathrm{X}_{8}$ (Kebijakan Pemerntah)

$\mathrm{X}_{8}=$ Kebijakan Pemerintah

$\beta 9=$ Koefisien regresi dari variabel $X_{9}$ (Pendidikan Petani) 
Faktor- Faktor yang Mempengaruhi Proses Alih Fungsi Lahan Padi Sawah di Kelurahan Kersanegara, Kecamatan Cibeureum, Kota Tasikmalaya, Provinsi Jawa Barat

$\mathrm{X}_{9}=$ Pendidikan Petani

$\mathrm{e}=$ standar error

\section{HASIL DAN PEMBAHASAN}

Faktor-faktor yang mempengaruhi terjadinya alih fungsi lahan padi sawah di Kelurahan Kersanagara Kecamatan Cibeureum Kota Tasikmalaya dapat dilhat dari hasil regresi liner berganda (Tabel 2). Sebelum dilakukan uji regresi, terlebih dahulu dilakukan uji asumsi klasik. Uji asumsi klasik merupakan syarat yang harus dipenuhi sebelum dilakukan uji analisis statistik lainnya. Agar uji analisis statistik lainnya dapat dilakukan, maka harus dipastikan bahwa tidak ada asumsi-asumsi yang dilanggar.

Tabel 2. Hasil analisis regresi linier berganda

\begin{tabular}{cccccccc}
\hline & \multicolumn{2}{c}{$\begin{array}{c}\text { Unstandardized } \\
\text { coefficients }\end{array}$} & \multicolumn{2}{c}{$\begin{array}{c}\text { Standardized } \\
\text { coefficients }\end{array}$} & & \multicolumn{2}{c}{$\begin{array}{c}\text { Collinearity } \\
\text { Statistic }\end{array}$} \\
\hline Model & B & $\begin{array}{c}\text { Std. } \\
\text { Error }\end{array}$ & Beta & T & Sig & Tolerance & VIF \\
\hline Constant) & 0,542 & 0,128 & & 4,225 & 0,000 & & \\
\hline Umur petani & $-0,003$ & 0,001 & $-0,380$ & $-2,495$ & 0,018 & 0,728 & 1,373 \\
\hline Pendapatan & $-1,748$ & 0,000 & $-0,242$ & $-1,201$ & 0,238 & 0,416 & 2,404 \\
\hline $\begin{array}{c}\text { Luas } \\
\text { kepemilikkan }\end{array}$ & 0,099 & 0,048 & 0,416 & 2,053 & 0,048 & 0,413 & 2,419 \\
\hline Sistem waris & $-0,012$ & 0,007 & $-0,254$ & $-1,853$ & 0,073 & 0,901 & 1,110 \\
\hline Tetangga & $-0,010$ & 0,006 & $-0,212$ & $-1,514$ & 0,139 & 0,861 & 1,162 \\
\hline Pengusaha & 0,009 & 0,007 & 0,182 & 1,254 & 0,218 & 0,803 & 1,245 \\
\hline $\begin{array}{c}\text { Kondisi } \\
\text { lingkungan }\end{array}$ & $-0,008$ & 0,007 & $-0,173$ & $-1,173$ & 0,249 & 0,777 & 1,288 \\
\hline $\begin{array}{c}\text { Kebijakan } \\
\text { pemerintah }\end{array}$ & 0,002 & 0,005 & 0,054 & 0,360 & 0,721 & 0,742 & 1,349 \\
\hline Pendidikan & $-0,054$ & 0,018 & $-0,506$ & $-2,984$ & 0,005 & 0,590 & 1,696 \\
\hline
\end{tabular}

\section{Uji F}

Hasil uji F berdasarkan tabel uji ANOVA atau F test (Tabel 3) didapatkan nilai F hitung sebesar 2,784 dengan angka signifikansi (p-value) sebesar 0,015 dan tingkat signifikansi 95\% $(\alpha=0,05)$. Oleh karena probabilitas jauh lebih kecil dari 0,05. Dapat disimpulkan bahwa koefisien regresi umur petani, pendapatan petani, luas kepemilikkan lahan, sistem waris, tetangga, pengusaha, kondisi lingkungan, kebijakan pemerintah dan pendidikan petani tidak sama dengan nol atau variabel independent secara keseluruhan berpengaruh terhadap alih fungsi lahan.

Tabel 3. Hasil uji F ANOVA

\begin{tabular}{llrrrrl}
\hline \multicolumn{1}{l}{ Model } & \multicolumn{1}{l}{ Sum of Squares } & Df & Mean Square & F & \multicolumn{1}{l}{ Sig. } \\
\hline 1. & Regression & 0,119 & 9 & 0,013 & 2,784 & $0,015^{\text {b }}$ \\
\cline { 2 - 7 } & Residual & 0,162 & 34 & 0,005 & & \\
\cline { 2 - 8 } & Total & 0,281 & 43 & & & \\
\hline
\end{tabular}




\section{Koefisien Determinasi $\left(\mathbf{R}^{2}\right)$}

Berdasarkan tabel 4, dapat dilihat bahwa nilai Adjusted $R^{2}$ adalah sebesar 0,272. Hal ini dapat diartikan bahwa variabel independent (umur petani, pendapatan petani, luas kepemilikkan lahan, sistem waris, tetangga, pengusaha, kondisi lingkungan, kebijakan pemerintah dan pendidikan petani) dapat menjelaskan variabel dependent (alih fungsi lahan) sebesar 27,2\%, sedangkan sisanya diterangkan oleh faktor lain di luar model.

Tabel 4. Koefisien determinasi Model Summary

\begin{tabular}{ccrrrr}
\hline Model & R & R Square & \multicolumn{1}{c}{$\begin{array}{c}\text { Adjusted R } \\
\text { Square }\end{array}$} & $\begin{array}{c}\text { Std. Error of } \\
\text { the Estimate }\end{array}$ & $\begin{array}{c}\text { Durbin- } \\
\text { Watson }\end{array}$ \\
\hline 1 & $0,651^{\mathrm{a}}$ & 0,424 & 0,272 & 0,06893 & 2,116 \\
\hline
\end{tabular}

\section{Uji Parsial (uji t)}

Untuk menginterpretasikan koefisien parameter variabel independen digunakan standardized coefficients (Tabel 2). Variabel-variabel independent yang dimasukkan ke dalam model adalah umur petani $\left(\mathrm{X}_{1}\right)$, pendapatan petani $\left(\mathrm{X}_{2}\right)$, luas kepemilikkan lahan $\left(\mathrm{X}_{3}\right)$, sistem waris $\left(\mathrm{X}_{4}\right)$, tetangga $\left(\mathrm{X}_{5}\right)$, pengusaha $\left(\mathrm{X}_{6}\right)$, kondisi lingkungan $\left(\mathrm{X}_{7}\right)$, kebijakan pemerintah $\left(\mathrm{X}_{8}\right)$ dan pendidikan petani $\left(\mathrm{X}_{9}\right)$ dengan variabel dependen alih fungsi lahan $(\mathrm{Y})$.

Berdasarkan hasil uji t didapatkan persamaan regresi sebagai berikut:

$$
\begin{aligned}
\mathrm{Y}= & -0,380 \mathrm{X}_{1}-0,242 \mathrm{X}_{2}+0,416 \mathrm{X}_{3}-0,254 \mathrm{X}_{4}-0,212 \mathrm{X}_{5}+0,182 \mathrm{X}_{6}-0,173 \mathrm{X}_{7}+0,054 \mathrm{X}_{8}- \\
& 0,056 \mathrm{X}_{9}
\end{aligned}
$$

Dari variabel-variabel yang digunakan pada penelitian ini, terdapat 3 variabel yang signifikan (Tabel 2). Variabel tersebut adalah umur petani $\left(X_{1}\right)$, luas kepemilikkan lahan $\left(X_{3}\right)$ dan pendidikan petani $\left(\mathrm{X}_{9}\right)$.

Berdasarkan hasil analisis regresi tersebut menunjukkan hasil sebagai berikut:

\section{Pengaruh umur petani $\left(\mathrm{X}_{1}\right)$ terhadap alih fungsi lahan padi sawah}

Koefisien regresi umur petani sebesar $-0,380$ dan signifikan menyatakan bahwa semakin muda umur petani maka ada kecenderungan untuk mengalihfungsikan lahannya. Hal ini terbukti dengan alih fungsi lahan yang terjadi di Kelurahan Kersanagara. mayoritas petani yang mengalihfungsikan lahannya berada pada umur produktif yaitu sebesar $64 \%$ banyak yang menyebabkan terjadinya alih profesi dari sektor pertanian ke nonpertanian.

Sejalan dengan yang di sampaikan oleh Mulyani dan agus [7] bahwa sektor pertanian dipandang tidak atraktif dibanding sektor lain, sehingga menyebabkan derasnya arus urbanisasi angkatan kerja dari pedesaan ke perkotaan atau dari sektor pertanian ke nonpertanian. Dalam hal ini berarti tidak ada regenerasi petani sehingga lahan - lahan sawah banyak dijual untuk di alih-fungsikan disebabkan tidak ada atau bahkan sangat jarang sekali anak para petani yang melanjutkan profesi orang tuanya menjadi petani. Akibatnya petani saat ini didominasi oleh usia - usia lanjut karena kurang diminati oleh generasi muda [8].

Selain karena itu, petani dengan umur tua cenderung mempertahankan lahannya karena kehidupan mereka bertumpu pada sektor pertanian. Mereka melakukan usahatani untuk konsumsi sendiri tidak untuk dijual (subsisten). Di usia nya yang telah lanjut/tua pun akan sulit mendapatkan pekerjaan lain di sektor nonpertanian, berbeda dengan petani yang masih berada di rentang umur sekitar $40-50$, mereka masih bisa alih profesi seperti menjadi buruh bangunan atau sopir atau bahkan berwirausaha di sektor nonpertanian dari hasil penjualan lahan yang akan di alih fungsikan oleh pembelinya. 
Berbeda dengan hasil penelitian [9] yang menunjukkan bahwa usia berpengaruh positif terhadap alih fungsi sawah di tingkat petani. Tanda positif berarti semakin besar usia, maka alih fungsi yang dilakukan juga semakin besar.

\section{Pengaruh pendapatan petani $\left(\mathrm{X}_{2}\right)$ terhadap alih fungsi lahan padi sawah}

Koefisien regresi pendapatan petani sebesar - 0,242 dan tidak signifikan. Artinya, alih fungsi lahan yang terjadi di Kelurahan Kersanagara tidak dipengaruhi oleh variabel ini. Sebesar 58\% responden pendapatan nya diperoleh dari pertanian dengan kontribusi sekitar $63,87 \%$ sampai $100 \%$. Hal ini berarti proporsi pendapatan petani di Kelurahan kersanagara di dominasi oleh pendapatan yang berasal dari sektor pertanian.

Menurut Nasoetion [10] keputusan petani untuk mengalih fungsikan lahan sawahnya memiliki peluang yang lebih besar pada rumah tangga petani dengan proporsi pendapatan usahatani padi sawahnya yang lebih kecil. Semakin tinggi proporsi pendapatan usahatani padi sawah terhadap pendapatan total rumah tangga maka semakin kecil peluang petani untuk mengalihfungsikan lahan sawahnya

\section{Pengaruh luas kepemilikkan lahan $\left(X_{3}\right)$ terhadap alih fungsi lahan padi sawah}

Koefisien regresi luas kepemilikkan lahan sebesar 0,416 dan signifikan. Artinya, setiap kenaikan luas kepemilikkan lahan satu satuan akan meningkatkan alih fungsi lahan sebesar 0,416 satuan. Berarti, semakin luas lahan sawah yang dimiliki petani maka akan semakin tinggi kecenderungan terjadinya alih fungsi lahan. Hasil penelitian Nasution [18] menyatakan bahwa luas sawah berpengaruh positif dan nyata terhadap alih fungsi lahan sawah di tingkat petani. Berarti semakin luas sawah yang dimiliki petani, maka semakin besar pula alih fungsi yang dilakukan. Keadaan tersebut seperti alih fungsi lahan yang terjadi di Kelurahan Kersanagara, petani pada awalnya menjual sebagian lahannya untuk di alih fungsikan oleh pembelinya walaupun pada akhirnya sampai menjual seluruh lahan yang dimilikinya untuk di alih fungsikan.

Akan tetapi adapun sebagian petani yang memiliki lahan kurang dari 0,1 namun menjual seluruh lahan yang dimiliki nya karena biaya produksi yang tinggi. Sejalan dengan Mulyani dan Agus (2006) yang menyatakan bahwa sempitnya kepemilikkan lahan pertanian dengan lahan garapan $<0,5$ ha menyebabkan pendapatan yang diterima petani tidak mampu menutup biaya produksi. Dalam hal ini akhirnya banyak petani yang menjual lahan pertaniannya utuk dialih fungsikan walaupun terpaksa harus kehilangan atau berkurang mata pencahariannya [2].

Menurut irawan [11] peningkatan harga lahan selanjutnya dapat merangsang petani untuk menjual lahan. Pernyataan tersebut sesuai dengan yang terjadi di Kelurahan Kersanagara, karena kelurahan ini terletak di pinggir jalan raya dan mendekati pusat Kota Tasikmalaya. Keadaan ini mendorong petani untuk melepaskan kepemilikkan lahannya karena beraggapan dengan menjual lahannya untuk dialih fungsikan maka hasil penjualan yang diperoleh akan besar.

Hasil penjualan lahan yang diterima dapat dibelikan lagi untuk lahan sawah di daerah lain dengan harga yang lebih murah sehingga lahan sawah yang dimiliki menjadi lebih luas dari lahan sawah yang sebelumnnya dijual untuk di alih fungsikan. Menurut Simatupang dan Irawan [12] sebagian hasil penjualan lahan tersebut biasanya digunakan untuk membeli lahan kembali dengan harga lebih murah, biasanya semakin menjauhi daerah perkotaan. Selain itu sebagian hasil penjualannya bisa digunakan juga untuk modal usaha di sektor nonpertanian. Akan tetapi untuk sebagian besar petani yang luas kepemilikkan lahannya sempit, mereka mejual lahannya untuk beralih profesi ke sektor nonpertanian.

\section{Pengaruh sistem waris $\left(\mathrm{X}_{4}\right)$ terhadap alih fungsi lahan padi sawah}

Koefisien regresi sistem waris sebesar - 0,254 dan tidak signifikan. Artinya, alih fungsi lahan yang terjadi di Kelurahan Kersanagara tidak dipengaruhi oleh sistem waris. Hanya 7\% responden yang mewariskan dan hanya 13 responden yang menerima warisan dalam bentuk lahan sawah. Menurut responden, warisan yang diterima atau yang di waris kansudah dalam bentuk rumah atau uang hasil 
penjualan lahan sawah. Hal ini di sebabkan karena lahan sawah yang di waris kan atau yang diterima sempit. Lahan sawah yang sempit kurang layak untuk diusahakan karena tidak memenuhi batas minimum skala ekonomi usaha yang dapat menguntungkan [2].

\section{Pengaruh tetangga yang mengalihfungsi lahannya $\left(X_{5}\right)$ terhadap alih fungsi lahan padi sawah}

Koefisien regresi tetangga yang mengalihfungsikan lahannya sebesar - 0, 212 dan tidak signifikan. Artinya, alih fungsi lahan yang terjadi di Kelurahan Kersanagara tidak di pengaruhi oleh variabel ini. Sebesar $40 \%$ responden menyatakan tidak terpengaruh dengan tetangga yang telah lebih dulu mengalihfungsikan/menjual lahannya.

Respondenakan mengalihfungsikan/mejual lahannya jika memang sedang dalam keadaan yang mendesak atau jika perlu untuk biaya pendidikan anak. Responden tidak peduli dengan keadaan tetangga yang telah lebih dulu menjual/alihfungsi lahan sawahnya. Petani tergoda untuk menjual lahan sawahnya kepada pihak lain manakala kebutuhan ekonomi makin mendesak untuk dipenuhi [3].

\section{Pengaruh investasi $\left(X_{6}\right)$ terhadap alih fungsi lahan padi sawah}

Koefisien regresi investasi sebesar 0,182 dan tidak signifikan. Artinya, alih fungsi lahan yang terjadi di Kelurahan Kersanagara tidak dipengaruhi oleh adanya investor. Investor mulai memasuki Kelurahan Kersanagara pada tahun 2016, sedangkan alih fungsi lahan telah banyak terjadi dari tahuntahun sebelumnya. Menurut responden masuknya investor ke Kelurahan Kersanagara diduga karena letak sebagian wilayah ini berada di sekitar jalan raya dan belum ada perumahan.

Dengan adanya investor ini secara tidak langsung dapat meningkatkan harga lahan sawah sebagai dampak dari pembangunan yang dilakukan oleh investor tersebut. Menurut Irawan [11] dengan adanya pengembangan atau pemukiman mendorong meningkatnya permintaan lahan oleh investor lain atau spekulan tanah sehingga harga lahan di sekitarnya meningkat.

\section{Pengaruh keadaan lingkungan $\left(\mathrm{X}_{7}\right)$ terhadap alih fungsi lahan padi sawah}

Koefisien regresi keadaan lingkungan sebesar - 0,173 dan tidak signifikan. Artinya, keadaan lingkungan tidak mempengaruhi terhadap terjadinya alih fungsi lahan padi sawah. $62 \%$ responden menyatakan bahwa keadaan lingkungan di Kelurahan Kersanagara masih menunjang untuk proses produksi budidaya padi sawah. Hal ini didasarkan pada tidak adanya pencemaran seperti pencemaran air atau tanah yang disebabkan oleh limbah buangan pabrik/industri. Akan tetapi, pada musim kemarau petani mengalami kesulitan air karena kondisi saluran irigasi kurang baik sehingga hanya bisa menanam pada musim hujan. Menurut Sumaryanto [4] mengemukakan bahwa irigasi yang kurang baik dapat menyebabkan lahan sawah tidak mampu berproduksi optimal. Petani berpendapat bahwa saluran irigasi menjadi kurang baik karena dampak dari banyaknya pembangunan pada lahan yang awalnya adalah lahan sawah. Hal ini mengakibatkan banyak saluran irigasi yang rusak sehingga sawah-sawah sekitarnya tidak mendapatkan aliran air irigasi.

\section{Pengaruh kebijakan pemerintah $\left(\mathbf{X}_{8}\right)$ terhadap alih fungsi lahan padi sawah}

Koefisien regresi kebijakan pemerintah sebesar 0,054 dan tidak signifikan. Artinya, kebijakan pemerintah tidak mempengaruhi terhadap terjadinya alih fungsi lahan padi sawah. Hal ini dikarenakan alih fungsi lahan yang terjadi di Kelurahan Kersanagara bukan dilakukan oleh pemerintah tetapi oleh pihak lain atau perorangan. Alih fungsi lahan padi sawah menjadi bangunan-bangunan rumah atau perumahan bukan menjadi jalan raya, sarana pendidikan atau sarana umum lainnya. Keadaan ini melanggar aturan mengenai LP2B yang melarang alih fungsi lahan untuk kepentingan perorangan dan pemerintah Kota Tasikmalaya selalu memberikan ijin kepada perorangan untuk melakukan pembangunan di wilayah LP2B.

Otonomi daerah yang mengutamakan pembangunan pada sektor yang menjanjikan keuntungan jangka pendek lebih tinggi sehingga kurang memperhatikan kepentingan jangka panjang dan kepentingan nasional [1]. Hal ini seperti yang terjadi di Kota Tasikmalaya yang banyak melakukan pembangunan

$$
\text { Jurnal Rekayasa Hijau - } 18
$$


Faktor- Faktor yang Mempengaruhi Proses Alih Fungsi Lahan Padi Sawah di Kelurahan Kersanegara, Kecamatan Cibeureum, Kota Tasikmalaya, Provinsi Jawa Barat

pada wilayah LP2B. Kepala BPP Kecamatan Cibeureum mengkhawatirkan mengenai ketersediaan pangan beberapa tahun ke depan. Pada tahun-tahun sekarang pun Kota Tasikmalaya tidak dapat mencukupi kebutuhan pangannya sehingga membutuhkan pasokan dari luar daerah.

\section{Pengaruh pendidikan petani $\left(X_{9}\right)$ terhadap alih fungsi lahan padi sawah}

Koefisien regresi pendidikan petani sebesar -0,056 dan signifikan menyatakan bahwa kenaikan satu satuan lama pendidikan petani akan menurunkan alih fungsi lahan sebesar 0,056 satuan. Artinya semakin tinggi pendidikan petani maka ada kecenderungan untuk mempertahankan lahan yang dimiliki agar tidak dialih fungsikan. Seperti yang diungkapkan bahwa semakin tinggi tingkat pendidikan maka akan semakin bijak dalam mengambil keputusan untuk mengambil keputusan untuk mengambil keputusan tidak melakukan alih fungsi lahan [2].

Tingkat pendidikan responden didominasi oleh petani berpendidikan tingkat SD, bahkan banyak yang tidak bersekolah. Kondisi ini menyebabkan mudahnya petani tergoda untuk menjual lahan sawahnya kepada pihak lain atau calo manakala kebutuhan ekonomi makin mendesak untuk dipenuhi.

\section{KESIMPULAN}

Faktor dominan yang mempengaruhi proses alih fungsi lahan padi sawah di Kelurahan Kersanagara, Kecamatan Cibeureum, Kota Tasikmalaya adalah luas kepemilikkan lahan dan umur petani. Semakin luas lahan petani maka alih fungsi lahan semakin tinggi dan semakin muda umur petani maka alih fungsi lahan semakin tinggi.

\section{DAFTAR PUSTAKA}

[1] Agus, F. \& Husen, E. (2005). Tinjauan umum multifungsi pertanian. In Seminar Nasional Multifungsi Pertanian dan Ketahanan Pangan. Bogor (Vol. 12).

[2] Adimihardja, A. (2006). Strategi mempertahankan multifungsi pertanian di Indonesia. Jurnal Litbang Pertanian, 25(3), 99.

[3] Nurmanaf, A. R., Mayrowani, H., \& Jamal, E. (2001). Evaluasi Sosial Ekonomi Multifungsi Lahan Sawah. In Proceeding of Seminar Nasional Multifungsi Lahan Sawah, Bogor (Vol. 1, pp. 121-142).

[4] Sumaryanto, S. F., \& Irawan, B. (2001). Konversi Lahan Sawah ke Penggunaan Non Pertanian dan Dampak Negatifnya. In Prosiding Seminar Nasional Multifungsi Lahan Sawah (pp. 1-18).

[5] Sugiyono. (2012). Metode penelitian kuantitatif kualitatif dan R\&D. Bandung: CV ALVABETA

[6] Ghozali, Imam. (2017). Ekonometrika Teori, Konsep Dan Aplikasi Dengan IBM SPSS 24. Semarang: Badan Penerbit Universitas Diponegoro

[7] Mulyani, A., \& Agus, F. (2006, June). Potensi lahan mendukung revitalisasi pertanian. In Mulfifungsi dan Revitalisasi Pertanian. Prosiding Seminar. Badan Penelitian dan Pengembangan Pertanian bekerjasama dengan Ministry of Agriculture, Forestry and FisheriesJapan, dan ASEAN Secretariat., Jakarta.

[8] Nasution, A. R., Tarigan, K., \& Ayu, S. F. (2016). Analisis Faktor-Faktor yang Mempengaruhi Alih Fungsi Lahan Padi Sawah dan Pengaruhnya Terhadap Pendapatan Petani (Studi Kasus: Desa Suka Maju Kecamatan Tanjung Pura Kabupaten Langkat). JOURNAL ON SOCIAL ECONOMIC OF AGRICULTURE AND AGRIBUSINESS, 4(7).

[9] Danapriatna, N., \& Panuntun, Y. U. (2016). Pengaruh konversi lahan pertanian terhadap tingkat kesejahteraan petani (Kasus di Kecamatan Setu, Kabupaten Bekasi). Jurnal faperta: cefars, 4(2)

[10] Nasoetion, L. I. (2003). Konversi Lahan Pertanian: Aspek Hukum Dan Implementasinya Agricultural Land Conversion: Judicial Aspect And Its Implementation.

[11] Irawan, B. (2005, August). Konversi lahan sawah: potensi dampak, pola pemanfaatannya, dan faktor determinan. In Forum Penelitian Agro Ekonomi (Vol. 23, No. 1, pp. 1-18).

[12] Simatupang, P., \& Irawan, B. (2003). Pengendalian konversi lahan pertanian: tinjauan ulang kebijakan lahan pertanian abadi agricultural land conversion control: re-examination of eternal agricultural land. 